\title{
Efficacy of Newer Molecules of Fungicides against Alternaria brassicae in vitro
}

\author{
Neeraj Kumar Rajvanshi*, H. K. Singh and Manish Kumar Maurya \\ Department of Plant Pathology, Acharya Narendra Deva University of Agriculture and \\ Technology Kumarganj, Ayodhya-224229 (U.P.) India \\ *Corresponding author
}

\section{Keywords}

Fungicides, Radial growth, Alternaria brassicae, in vitro

Article Info

Accepted:

20 August 2020 Available Online:

10 September 2020

\begin{abstract}
A B S T R A C T
Rapeseed-mustard belongs to family Brassicaceae. It is the most important group of rabi oilseed crops and contribute a major share to the vegetable fat of the country. Effectiveness of the six fungicides i.e. Quintal (Iprodione 25\% + Carbendazim 25\%), Nativo (Tebuconazole 50\% + Trifloxystrobin 25\% 75GW), Tilt (Propiconazole 25 EC), Score (Difenoconazole 25 EC) and Propineb (Antracol 70 WP), Folicur (Tebuconazole 250 EC) were used at three concentrations of each @ 0.05, 0.1 and 0.2 per cent and one is no treatment (control) under in vitro against Alternaria brassicae by poison food technique. At $0.05 \%$ concentration of fungicides the minimum growth was recorded in Iprodione $25 \%$ + Carbendazim 25\% (47.47mm) followed by Propineb $70 \mathrm{WP}(52.56 \mathrm{~mm})$ had significantly reduced the mycelia growth of tested pathogen by food poison technique than the control $(90.00 \mathrm{~mm})$. In case of $0.1 \%$ concentration of fungicides the minimum growth was recorded in Iprodione $25 \%$ + Carbendazim $25 \%$ (38.09mm) followed by Propineb 70 WP $(43.00 \mathrm{~mm})$ had significantly reduced the mycelia growth of tested pathogen than the control $(90.00 \mathrm{~mm})$. In case of $0.2 \%$ concentration of fungicides the minimum growth was recorded in Iprodione $25 \%+$ Carbendazim $25 \%(27.84 \mathrm{~mm})$ followed by Propineb 70 WP $(30.84 \mathrm{~mm})$, had significantly reduced the mycelia growth of tested pathogen than the control $(90.00 \mathrm{~mm})$. Four treatments namely Tebuconazole 250 EC + Trifloxystrobin WG 75; Propiconazole 25 EC; Difenoconazole 25 EC and Tebuconazole $250 \mathrm{EC}$ were tested by poison food technique in vitro and result cent per cent restriction of radial growth of Alternaria brassicae in $0.05 \%, 0.1 \%$ and $0.2 \%$ concentration.
\end{abstract}

\section{Introduction}

Rapeseed-mustard belongs to family Brassicaceae, which is grown in northern India comprising traditionally grown indigenous species namely Indian mustard $(B$. juncea), brown sarson (B. campestris var. brown sarson), yellow sarson (B. campestris var. yellow sarson), toria (B. campestris var. toria), taramira (Eruca sativa), gobhi sarson (B. napus), white mustard (B. alba) and Ethiopian mustard (B. carinata). It is the most important group of rabi oilseed crops and contribute a major share to the vegetable fat of the country. Oil and fats comprise a vital component of human diet as these are good 
source of energy and act as carriers of fat soluble vitamins. The seeds are highly nutritive containing eruic acid (0-52.56\%), linoleic acid (6.30-41.80\%) and oleic acid (2.91-45.02\%), eicosenoic acid (0.0-17.61).

Oil cake or meal is used as a source of protein in animal feeds (Singh et al., 2011). Among the major growing countries of rapeseedmustard worldwide, India, Canada, China, Pakistan, Bangladesh, Germany, France, Sweden and Poland. In India, it had the area of 5.96 Million hectares with production of 8.32 Million Tonnes and productivity of 1397 $\mathrm{Kg} / \mathrm{hectare}$. In India, its cultivation is mainly confined to U.P., M.P., Rajasthan, Haryana, Assam, Gujarat, Jharkhand, Bihar, Punjab and West Bengal. State wise in U.P. it was grown on 0.68 Million hectares with production of 0.95 Million Tonnes and productivity of 1392 $\mathrm{Kg} / \mathrm{ha}$ and ranked third after M.P. and Rajasthan for area and second in production after Rajasthan (Anonymous, 2018). Behind the lower productivity of the crop, a number of fungal foliar diseases are most important.

This crop suffers from devastating diseases such as Alternaria blight, white rust, downy mildew, powdery mildew, bacterial rot and wilt (Kolte, 1985 and Singh et al., 2019). Among the diseases Alternaria blight caused by Alternaria brassicae (Berk) Sacc, are also widely prevalent diseases in Eastern Uttar Pradesh (Singh and Singh (2005) and Kumar et. al. (2016).

The blight also reduces seed size and impairs seed colour and oil content. In the absence of resistant cultivars, fungicides (Singh and Singh, 2005) provide the most reliable means of disease control. The efforts were made to search efficacious fungicides, for the management of this disease against the blight causing pathogen (Alternaria brassicae). Results of are being reported here.

\section{Materials and Methods}

Infected mustard leaf showing characteristic symptoms of Alternaria brassicae were collected from experimental field at Student Instructional Farm situated at main campus of Acharya Narendra Deva University of Agriculture and Technology, Kumarganj, Ayodhya (U.P.) for isolation and identification. The infected plant parts were cut in to small pieces and surface sterilized with 0.1 per cent mercuric chloride $\left(\mathrm{HgCl}_{2}\right)$ solution and washed thoroughly 3 to 4 times with sterilized water to remove the traces of $\mathrm{HgCl}_{2}$. The pieces were transferred in Petridishes containing potato dextrose agar and incubated at $25^{\circ} \mathrm{C}$ for 6 days. Effectiveness of the six fungicides i.e. Quintal (Iprodione 25\% + Carbendazim 25\%), Nativo (Tebuconazole 50\% + Trifloxystrobin 25\% 75GW), Tilt (Propiconazole 25 EC), Score (Difenoconazole 25 EC) and Propineb (Antracol 70 WP), Folicur (Tebuconazole 250 EC) were used at three concentrations of each @ $0.05,0.1$ and 0.2 per cent. Each concentration of fungicide was bio-assayed against the test pathogen under laboratory condition to find out their relative efficacy for inhibiting the mycelial growth of the pathogen in culture by poison food technique. Requisite quantity of each fungicide was incorporated in $100 \mathrm{ml} \mathrm{PDA}$ and mixed thoroughly by sacking, prior to pouring into Petriplates.

After the pouring of PDA in Petriplates, the medium was allowed to solidify and these plates were centrally inoculated with the 6 $\mathrm{mm}$ diameter disc of pathogen which is cut by sterilized cork borer, taken from the margin of actively growing 7 days old culture. Control was used as such without adding fungicide in the medium. Four replications of each treatment incubated at $26 \pm 2{ }^{\circ} \mathrm{C}$ for growth of the pathogen. The efficacy of various chemicals was observed by measuring radial 
growth of the fungal colony in millimeters $(\mathrm{mm})$. The inhibition evaluation was evaluated in terms of per cent inhibition of fungal growth was compared to the check. The efficacy of various fungicides was assessed by measuring the linear growth of the fungus. The per cent inhibition of mycelia growth was calculated by using the following formula:

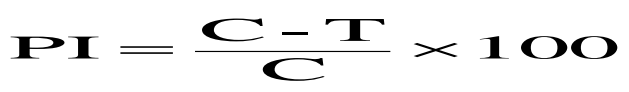

Where,

$\mathrm{PI}=$ Percentage inhibition over control

$\mathrm{C}=$ Radial growth of the pathogen in control (mm)
$\mathrm{T}=$ Radial growth of the pathogen in treatment (mm)

\section{Results and Discussion}

Seven treatments were evaluated under in vitro against Alternaria brassicae by poison food technique in $0.05 \%, 0.1 \%$ and $0.2 \%$ concentration. Data of the results (Table-1 and Fig. 1) revealed that the $0.05 \%$ concentration of fungicides, the minimum growth was recorded in $\mathrm{T}_{1=}$ Iprodione $25 \%+$ Carbendazim 25\% (47.47mm) followed by $\mathrm{T}_{5=}$ Propineb 70 WP $(52.56 \mathrm{~mm})$, had significantly reduced the mycelia growth of tested pathogen by food poison technique than the control $(90 \mathrm{~mm})$.

Table.1 In vitro effect of fungicides at different concentrations on radial mycelia growth and inhibition of Alternaria brassicae

\begin{tabular}{|c|c|c|c|c|c|c|}
\hline \multirow[t]{3}{*}{ Treatments } & \multicolumn{6}{|c|}{ Mycelial growth in (mm) } \\
\hline & \multicolumn{2}{|c|}{ Concentration $0.05 \%$} & \multicolumn{2}{|c|}{ Concentration $0.1 \%$} & \multicolumn{2}{|c|}{ Concentration $0.2 \%$} \\
\hline & $\begin{array}{c}\text { Radial } \\
\text { growth } \\
\text { (mm) }\end{array}$ & $\begin{array}{c}\text { Inhibition } \\
\quad(\%)\end{array}$ & $\begin{array}{l}\text { Radial } \\
\text { growth } \\
\text { (mm) }\end{array}$ & $\begin{array}{c}\text { Inhibition } \\
\quad(\%)\end{array}$ & $\begin{array}{l}\text { Radial } \\
\text { growth } \\
\text { (mm) }\end{array}$ & $\begin{array}{c}\text { Inhibition } \\
(\%)\end{array}$ \\
\hline 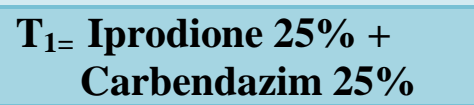 & 47.47 & $\begin{array}{c}47.25 \\
(43.42)^{*}\end{array}$ & 38.09 & $\begin{array}{c}57.67 \\
(49.36)\end{array}$ & 27.84 & $\begin{array}{c}69.62 \\
(56.20)\end{array}$ \\
\hline $\begin{aligned} & T_{2=} \text { Tebuconazole } 250 \\
& \text { EC + Trifloxystrobin } \\
& \text { WG } 75\end{aligned}$ & 0.00 & $\begin{array}{l}100.00 \\
(90.00)\end{array}$ & 0.00 & $\begin{array}{l}100.00 \\
(90.00)\end{array}$ & 0.00 & $\begin{array}{l}100.00 \\
(90.00)\end{array}$ \\
\hline $\begin{array}{l}\mathbf{T}_{3=} \text { Propiconazole } 25 \\
\text { EC }\end{array}$ & 0.00 & $\begin{array}{l}100.00 \\
(90.00)\end{array}$ & 0.00 & $\begin{array}{l}100.00 \\
(90.00)\end{array}$ & 0.00 & $\begin{array}{l}100.00 \\
(90.00)\end{array}$ \\
\hline $\begin{array}{l}\mathbf{T}_{4=} \text { Difenoconazole } 25 \\
\text { EC }\end{array}$ & 0.00 & $\begin{array}{l}100.00 \\
(90.00)\end{array}$ & 0.00 & $\begin{array}{l}100.00 \\
(90.00)\end{array}$ & 0.00 & $\begin{array}{l}100.00 \\
(90.00)\end{array}$ \\
\hline $\mathrm{T}_{5=}$ Propineb $70 \mathrm{WP}$ & 52.56 & $\begin{array}{c}41.60 \\
(40.16)\end{array}$ & 43.00 & $\begin{array}{c}52.22 \\
(46.27)\end{array}$ & 30.84 & $\begin{array}{c}66.03 \\
(54.17)\end{array}$ \\
\hline $\begin{array}{l}T_{6=} \text { Tebuconazole } 250 \\
\text { EC }\end{array}$ & 0.00 & $\begin{array}{l}100.00 \\
(90.00)\end{array}$ & 0.00 & $\begin{array}{l}100.00 \\
(90.00)\end{array}$ & 0.00 & $\begin{array}{l}100.00 \\
(90.00)\end{array}$ \\
\hline $\mathbf{T}_{7=}$ Control & 90.00 & $\begin{array}{c}0.00 \\
(0.00)\end{array}$ & 90.00 & $\begin{array}{c}0.00 \\
(0.00)\end{array}$ & 90.00 & $\begin{array}{c}0.00 \\
(0.00)\end{array}$ \\
\hline SEm \pm & 0.17 & 0.11 & 0.16 & 0.10 & 0.24 & 0.16 \\
\hline CD at $5 \%$ & 0.52 & 0.33 & 0.50 & 0.32 & 0.75 & 0.51 \\
\hline C.V. $(\%)$ & 1.09 & 0.30 & 1.16 & 0.28 & 2.03 & 0.43 \\
\hline
\end{tabular}

*Figure in parenthesis are angular transformed value 


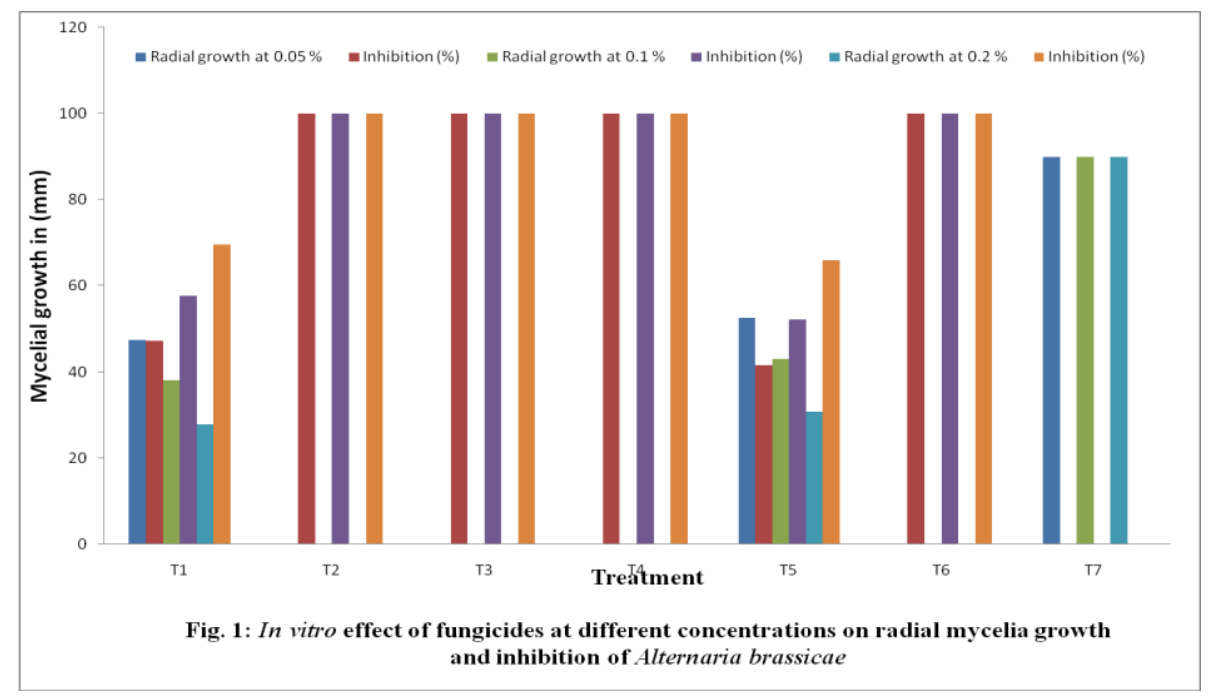

In case of $0.1 \%$ concentration of fungicides the minimum growth was recorded in $\mathrm{T}_{1=}$ Iprodione $25 \%+$ Carbendazim 25\% $(38.09 \mathrm{~mm})$ followed by $\mathrm{T}_{5=}$ Propineb $70 \mathrm{WP}$ $(43.00 \mathrm{~mm})$, had significantly reduced the mycelia growth of tested pathogen by food poison technique than the control $(90.00 \mathrm{~mm})$. In case of $0.2 \%$ concentration of fungicides the minimum growth was recorded in $\mathrm{T}_{1=}$ Iprodione $25 \%+$ Carbendazim 25\% $(27.84 \mathrm{~mm})$ followed by $\mathrm{T}_{5}$ Propineb $70 \mathrm{WP}$ $(30.84 \mathrm{~mm})$, had significantly reduced the mycelia growth of tested pathogen by food poison technique than the control $(90.00 \mathrm{~mm})$. Four treatments namely $\mathrm{T}_{2}$ (Tebuconazole 250 $\mathrm{EC}+$ Trifloxystrobin WG 75), $\mathrm{T}_{3}$ (Propiconazole $25 \mathrm{EC}$ ), $\mathrm{T}_{4}$ (Difenoconazole $25 \mathrm{EC}$ ) and $\mathrm{T}_{6}=($ Tebuconazole $250 \mathrm{EC})$ were tested by poison food technique in vitro and result cent per cent restriction of radial growth of Alternaria brassicae in $0.05 \%, 0.1 \%$ and $0.2 \%$ concentration. Highest per cent inhibition of mycelial growth was recorded in $\mathrm{T}_{1=}$ Iprodione 25\% + Carbendazim 25\% (47.25\%) followed by $\mathrm{T}_{5=}$ Propineb $70 \mathrm{WP}$ $(41.60 \%)$ at $0.05 \%$ concentration of fungicides. Results presented in Table-1 showed that highest per cent inhibition of mycelial growth was recorded in $\mathrm{T}_{1=}$ Iprodione 25\% + Carbendazim 25\% (57.67\%) followed by $\mathrm{T}_{5=}$ Propineb $70 \mathrm{WP}$ (52.22\%) at
$0.1 \%$ concentration of fungicides. Results presented in (Table-1) showed that highest per cent inhibition of mycelial growth was recorded in $\mathrm{T}_{1=}$ Iprodione $25 \%+$ Carbendazim 25\% (69.62\%) followed by $\mathrm{T}_{5=}$ Propineb 70 WP (66.03\%) at $0.2 \%$ concentration of fungicides. Four treatments namely $\mathrm{T}_{2}=$ Tebuconazole $250 \quad \mathrm{EC}+$ Trifloxystrobin WG 75, $\mathrm{T}_{3}$ Propiconazole 25 EC, $\mathrm{T}_{4}=$ Difenoconazole $25 \mathrm{EC}$ and $\mathrm{T}_{6}=$ Tebuconazole 250 EC were highly effective for inhibiting the growth (100\%) in $0.05 \%$, $0.1 \%$ and $0.2 \%$ concentration. Meena et al., (2004) and Biswas and Ghosh (2018) evaluated bio-control agent (Trichoderma viride) and fungicides (Mancozeb and Carbendazim) for controlling Alternaria blight in Indian mustard. Fungicide Mancozeb and Carbendazim caused $100 \%$ reduction in mycelia growth, while the bio-control agent significantly reduced disease severity. Khan et al., (2007) and Singh et al., (2008) tested efficacy of different fungicides (Apron 35 SD, Ridomil MZ 72 WP and Carbendazim 50\%) and bioagent (Trichoderma harzianum and Pseudomonas flurescence) alone and in combination against Alternaria blight and found seed treatment with Trichoderma harzianum@10g/kg seed + 3 foliar sprays of same bioagent @10\% was most effective in minimizing the disease intensity. 


\section{References}

Anonymous (2018). Agricultural Statistics at a Glance 2018, Government of India Ministry of Agriculture \& Farmers Welfare Department of Agriculture, Cooperation \& Farmers Welfare Directorate of Economics and Statistics. pp. 110-112.

Biswas, M.K. and Ghosh T. (2018). Evaluation of phyto-extracts, biological agents and chemicals against the development of Alternaria brassicae In vitro and In vivo. EJMP. 22 (3): 1-9.

Khan, M.M., Khan, R.U. and Mohiddin, F.A. (2007) Studies on the cost- effective management of Alternaria blight of rapeseed-mustard (Brassica spp.) Phyto pathologia-Mediterranea 46 (2):201206.

Kolte, S.J. (1985). Diseases of Annual Edible Oilseed Crops. Volume II RapeseedMustard and Sesame Diseases. C.R.C. Press. Inc. Boca. Raton, Florida pp. 135.

Kumar, A., Kumar R., Kumar, S., Nandan, D., Channd, G. and Kolte, S.J. (2016). Alternaria blight of oilseed brassicas: A review on management strategies through conventional, non-conventional and biotechnological approaches. $J$. Appl. \& Nat. Sci. 8 (2): 1110-1125.

Kumar, A. and Singh, S.N. (2018). Morphological variability among isolates of Alternaria brassicae (Berk.) Sacc. causing leaf blight of mustard. International Journal of Chemical
Studies, 6(3): 2820-2822.

Meena, P.D., Meena, R.L., Chattopadhyay, C. and Kumar, A. (2004). Identification of critical stages of disease development and bio-control of Alternaria blight of Indian mustard. Indian J. Phytopathol. 15 (4): 204-209.

Singh, H.K., Singh, R. B., Singh, M. and Singh, R. (2019). Diseases of rapeseed and mustard and their management. (Diseases of Oilseed Crops and Their Management Edited by Singh, H.K., Singh, R. B., Singh Published by Daya Publishing House-A Division of Astral International Pvt. Ltd., 4736/23, Ansari Road, Darya Ganj, New Delhi. ISBN 978-93-5124-987-0 (HB) PP.-137-212.

Singh, J.P., Singh, H.K. and Singh, R.B. (2008) Integrated management of foliar diseases of mustard. Indian phytopath. 61 (3): 408-409

Singh, M. and Singh, H.K. (2014). Morphological and cultural variability in alternaria brassicae isolates of Indian mustard, Brassica juncea L. Czern \& Coss. in Uttar Pradesh. Trends Biosciences, 7(20): 3125-3128.

Singh, R.B. and Singh, R.N. (2005). Status and management of foliar diseases of timely sown mustard in mid eastern India. Pl. Dis. Res. 20 (1): 18-24.

Singh, S., Singh, R.P., Singh, H.K., and Kumar, K. (2011). Fatty acid profile of some promising genotypes of Indian mustard. Plant Archives. 11 (2): 10791082.

\section{How to cite this article:}

Neeraj Kumar Rajvanshi, H. K. Singh and Manish Kumar Maurya. 2020. Efficacy of Newer Molecules of Fungicides against Alternaria brassicae in vitro. Int.J.Curr.Microbiol.App.Sci. 9(09): 3150-3154. doi: https://doi.org/10.20546/ijcmas.2020.909.389 